\title{
Due Process in Selective Service Appeals
}

The appeal board is the final authority within the Selective Service System. ${ }^{1}$ Like the local board, it is required to examine all the evidence presented by the registrant and to place him in the lowest of the nineteen classifications presently prescribed by regulation. ${ }^{2}$ Only those classified 1-A (available for military service), 1-A-O (conscientious objector available for noncombatant service), or 1-O (conscientious objector available for civilian service) may be drafted.

The Selective Service registrant reaches the appeal board upon his official protest of unfavorable classification by the local board. ${ }^{3}$ The critical importance of fairness at that level is mandated by the procedural context in which the appeal takes place. First, the appeal board is required by regulations to undertake a de novo review-an entirely new consideration of the registrant's classification. ${ }^{4}$ Therefore, the validity of the appeal board's decision, and not the actions of the local board, will be the subject of any judicial review that follows. ${ }^{5}$ Second,

1 See Selective Service Regulations, 32 C.F.R. \$ 1600 et seq. (1971). These regulations are undergoing rapid revision, the latest and most drastic in response to the Military Selective Service Act of 1971, 92d Cong., 1st Sess., Pub. L. No. 92-129 [hereinafter cited as 1971 Act]. Regulations issued pursuant to the Military Selective Service Act of 1967, 50 U.S.C. App. $\$ 451$ et seq. (1970) [hereinafter cited as 1967 Act], will hereinafter be cited as Old Reg. $\$$ - Regulations issued pursuant to the 1971 Act will be cited as New Reg. $\S-$. The New Regulations were issued in two parts, the latter superseding part of the former: 36 Fed. Reg. 23372-85 (1971); 37 Fed. Reg. 5120-35 (1972). Regulations unchanged by the 1971 Act will hereinafter be cited as Regs. \$ - The role of the appeal boards is determined by New Reg. §§ 1626-27.

2 The classification structure is established by New Reg. $\$ 1622$.

8 New Reg. \& 1626 controls the entitlement to and mechanics of the appeal. This appeal may be before the appeal board with jurisdiction over either the registrant's local board or his current place of employment or residence. Reg. \$ 1626.3(b). If the registrant is denied the classification he seeks by a divided vote of the appeal board, he may take a further appeal to the National Appeal Board under the procedures of Reg. § 1627. Because the analysis of issues for the National Appeal Board is exactly the same as that for the other appeal boards, the former will not be specifically dealt with. All of the appeal boards are charged only with the duty of finding facts and effecting the correct classification. None has any rule-making authority.

4 Reg. \$ 1626.4(h); see United States v. Grownfield, 439 F.2d 839, 3 SEL. SERv. L. REP. 3833 (3d Cir. 1971) [hereinafter cited as SSLR]; Forsting v. United States, 429 F.2d 134, 3 SSLR 3196 (8th Cir. 1970). See generally L. HERShEY, LEGAL AsPECTS OF SELECTIVE SERVICE (rev. ed. 1969); Comment, Judicial Development of the Law of Selective Service Reopening, 69 Micr. L. REv. 1074 (1971).

5 In general, the de novo classification by the appeal board is allowed to stand even though the local board has committed error. It is presumed that the appeal board con- 
the appeal board proceeding is attended by a presumption of regularity. ${ }^{6}$ In the absence of contrary evidence, all actions of the appeal board are presumed to be correct. Third, the evidence needed to rebut the presumption is difficult if not impossible to obtain. Records are kept only of the classification sought, the classification awarded, and the vote. ${ }^{7}$ Even if the registrant appears, he is not entitled to record the meeting, ${ }^{8}$ and the deliberations are conducted in secret. ${ }^{9}$ Finally, the scope of

sideration cured the local board's error. Hearings on the Administration and Operation of the Draft Law Before the Special Subcomm. on the Draft of the House Comm. on the Armed Services, 91st Cong., 2d Sess., ser. 91-80, at 12861-70 (1970) [hereinafter cited as House Hearings]; see United States v. Dudley, 436 F.2d 1057, 3 SSLR 3697 (6th Gir. 197I); United States v. Leavy, 422 F.2d 1155, 2 SSLR 3578 (9th Cir. 1970) (appeal board review cures lack of evidence before local board); United States v. White, 421 F.2d 487, 2 SSLR 3423 (5th Cir. 1969); Storey v. United States, 370 F.2d 255 (9th Cir. 1966); United States v. Neverline, 266 F.2d 180 ( 3 d Cir. 1959). Not all cases go to the extreme limit of allowing all local board errors to be cured by an appeal. There are at least two other lines of cases. In one line, the appeal board is held to have effected no cure where it may have been induced into prejudice against the registrant by some local board error. Atherton v. United States, 430 F.2d 741, 3 SSLR 3265 (9th Gir. 1970); United States v. French, 429 F.2d 391, 3 SSLR 3096 (9th Cir. 1970); Caverly v. United States, 429 F.2d 92, 3 SSLR 3194 (8th Cir. 1970); United States v. Vlasits, 422 F.2d 1267, 2 SSLR 3663 (4th Cir. 1970); United States v. Pebbles, 220 F.2d 114 (7th Cir. 1955); United States ex rel. Berman v. Craig, 207 F.2d 888 (3d Gir. 1953). In the other line, some specific errors of the local board are isolated, and it is held that errors of this particular sort will not be deemed cured by the appeal. United States v. Speicher, 439 F.2d 104, 3 SSLR 3850 (3d Cir. 1971) (appeal board not informed of reasons for local board action); United States v. Freeman, 338 F.2d 246, I SSLR 3012 (7th Cir. 1968) (failure to reopen); United States ex rel. de Julio v. Cooksey, - F. Supp. - 4 SSLR 3641 (D.N.J. 1971) (local board failure to schedule meeting with appeal agent); United States v. Jagla, 330 F. Supp. 262, 3 SSLR 3541 (N.D. Cal. 1970) (adverse information in file not shown to registrant).

6 E.g., United States v. Harris, 436 F.2d 775, 3 SSLR 3713 (9th Cir. 1970), cert. denied, 402 U.S. 981, rehearing denied, 403 U.S. 924 (1971). The presumption is rebuttable upon an affirmative showing by the registrant. At no time does the Government assume the burden of showing procedural regularity. United States v. Bowen, 414 F.2d 1268, 2 SSLR 3165 (3rd Cir. 1969).

7 Reg. $\S \S 1604.27,1626.21,1626.27$.

8 Letter to All State Directors 00-43, SSLR 2200:89 (Oct. 26, 1971).

9 There are no provisions allowing the registrant to be present during deliberations or requiring the board to disclose matters considered. See Hearings on S. Res. 39 Before the Subcomm. on Administrative Practice and Procedure of the Senate Comm. on the Judiciary, 91st Cong., Ist Sess. 74 (1969) [hereinafter cited as Senate Hearings]; cf. United States v. Dudley, 436 F.2d 1057, 3 SSLR 3697 (6th Cir. 1971). The only effective way to glean information about the appeal board's procedure in a particular case is to question the board's secretary. Interrogation of the members themselves is usually not allowed under the doctrine of United States v. Morgan, 313 U.S. 409 (1941). See Clay v. United States, 397 F.2d 901, 913, 1 SSLR 3088, 3092 (5th Cir. 1968), vacated and remanded on other grounds, 394 U.S. 310, 1 SSLR 3358 (1969), rehearing en banc denied, 422 F.2d 1330 (5th Cir.), conviction aff'd, 430 F.2d 156, 3 SSLR 3100 (5th Cir.), petition for rehearing denied, 3 SSLR 3248 (5th Cir. 1970), rev'd on other grounds, 403 U.S. 698, 4 SSLR 3258 (1971). Even questioning the secretary is of but limited value since years may have elapsed since the appeal was decided, and the board may have decided hundreds of cases on the day in question. 
review in Selective Service cases is the "narrowest known to the law"; board determinations will be upset only if there is no basis in fact to support them. ${ }^{11}$ As a practical matter, then, the decision of the appeal board is in most cases final, as to both the relevant facts and the application of the law to them. ${ }^{12}$

In this context of finality, the procedural safeguards afforded the registrant are of substantial interest. Currently, the registrant is entitled to appear personally before the appeal board and to be informed, by a

10 Blalock v. United States, 247 F.2d 615, 619 (4th Cir. 1957).

11 Estep v. United States, 327 U.S. 114 (1946). This basis in fact test was introduced by Estep to create judicial review of classifications in criminal proceedings. Previously there had been no review at all except by habeas corpus after the registrant had accepted induction. United States ex rel. Hull v. Stalter, 151 F.2d 633 (7th Gir. 1945). There is some evidence in the Estep opinion that the Court was searching for a way to liberalize substantially the law, but the interpretation of Estep by the lower courts has been exceedingly narrow, and the Supreme Court itself later interpreted "basis in fact" to mean that the tiniest scintilla of evidence would support the conviction. Witmer v. United States, 348 U.S. 375, 380 (1955); United States v. Salamy, 379 F.2d 838, 84I (10th Cir. 1967); Blalock v. United States, 247 F.2d 615 (4th Cir. 1957); see Note, An Examination of Fairness in Selective Service Procedure, 37 GEo. WASH. L. Rev. 564, 579 (1969). See also Hansen, The Basis-in-Fact Test in Judicial Review of Selective Service Reclassifications: A Critical Analysis, 37 Brooksyn L. Rev. 453 (1971). An examination of recent cases suggests that there may be a gradual return to the more liberal rule that Estep attempted to create. United States v. O'Bryan, 450 F.2d 365, 4 SSLR 3678 (6th Cir. 1971); cf. 4 K.C. Davis, Administrative Law Treatise of 28.12 (1970 Supp.). The cases now seem to establish four separate means of circumventing the rigid basis in fact test. First, some fact situations can no longer be bases in fact for particular classifications. E.g., United States v. Broyles, 423 F.2d 1299, 2 SSLR 3562 (4th Cir. 1970) (late claim); United States v. White, 421 F.2d 487, 2 SSLR 3423 (5th Cir. 1969) (atheism does not debar 1-0 claim); United States v. Owen, 415 F.2d 383, 2 SSLR 3233 (8th Cir. 1969) (claiming many deferments does not impugn sincerity); see Comment, Fairness and Due Process Under the Selective Service System, 114 U. PA. L. REv. 1014, 1020 (1966). Second, the basis-in-fact test is also avoided by disallowing board decisions that, while possibly having a valid basis in fact, reflect an erroneous interpretation of the law. Clay v. United States, 403 U.S. 698 (1971); United States v. Seeger, 380 U.S. 163 (1965); Sicurella v. United States, 348 U.S. 385 (1955). Third, where the board does not give reasons permitting determination whether it relied on a valid basis in fact, the conviction is often overturned. See text and notes at notes $141-49$ infra. Finally, where there is a valid basis in fact, but a procedure arguably prejudicial to the registrant has been followed, that basis may be overridden by the faulty procedure. See generally Sedler, The Procedural Defense in Selective Service Prosecutions: The View From Without and Within, 56 Iowa L. Rev. 1121 (1971).

12 See Sedler, supra note 11, at 1189; Note, Local Board Processing of Conscientious Objectors, 1971 WrSc. L. REv. 318, 327 (1971). See generally Reisner, Selective Service Appeal Boards and the Conscientious Objector Claimant: Congressional Standards and Administrative Behavior, 1971 WIsc. L. REv. 521. Among the cases, see, for example, United States v. Pompey, 445 F.2d 1313, 4 SSLR 3405 (3rd Cir. 1971). If the registrant fails to perfect an appeal at all, he is often barred from presenting his defense to the court since he has failed to exhaust his administrative remedies. Compare Barnes v. United States, 387 F.2d 649 (5th Cir. 1967), with McKart v. United States, 395 U.S. 185, 2 SSLR 3023 (1969), and Bradley v. Laird, 449 F.2d 898, 4 SSLR 3665 (10th Cir. 1971). 
brief statement, of the reasons for the appeal board's decision. ${ }^{13}$ Both rights are innovations created by the 1971 extension of the Military Selective Service Act, but not implemented by regulation until February, 1972. (This failure either to allow a personal appearance or to provide reasons is of more than historical interest. Many cases involving these registrants are currently before the courts; still others are yet to be filed.) Almost no other provision of the Act are relevant to the functioning of the appeal boards, which are governed in general by regulations of the "housekeeping" variety.14 Nor does the registrant receive the other procedural safeguards normally associated with administrative adjudications. ${ }^{16} \mathrm{He}$ is not allowed to be accompanied by counsel, ${ }^{16}$ to confront adverse witnesses, ${ }^{17}$ to introduce witnesses on his own behalf, ${ }^{18}$ or to have access to a transcript of the proceedings. ${ }^{19} \mathrm{He}$ has no right to hear or to rebut any preliminary opinion the board may have formed about his case. ${ }^{20}$

The absence of traditional due process safeguards here is underscored by the presence of these safeguards in other adjudicatory proceedings

13 New Reg. § 1626.

141967 Act $\S 460(\mathrm{~b})$ contains the only relevant provisions. Most regulations deal with such matters as the qualifications of members and codes of honesty. Reg. $\S \S 1600,1603$. All crucial appeal board regulations are collected under Reg. $\$ 1626$, which itself does little more than require the board to consider the claim and direct how papers are to be routed.

15 Compare Reg. $\S \S 1600$ et seq. with Administrative Procedure Act, 5 U.S.C. $\$ \S 551$ et seq. (1970). The Selective Service System is specifically exempted from all but the freedom-of-information and prepublication-of-rules sections of the Administrative Procedure Act. United States v. McDuffie, 433 F.2d 1163, 4 SSLR 3427 (5th Gir. 1971); Administrative Procedure Act, 5 U.S.C. § 551 et seq. (1970); 1967 Act \$ 463(b); 1971 Act § 101(a)(32).

16 New Reg. $\$ 1626.4$ does not permit anyone to accompany the registrant to the appearance before the appeal board. New Reg. \& 1624.4(e) specifically forbids anyone acting as counsel to accompany the registrant before the local board. This prohibition has been upheld in ten of the eleven circuits. See United States v. Hosmer, 434 F.2d 209 (lst Cir.), cert. denied, 401 U.S. 978 (1971); cases collected in Note, Prohibition of Counsel at Selective Service Proceedings: The Impact of the Weller Case, 20 Catrolic U.L. REv. 478 (1971). Contra, United States v. Weller, 309 F. Supp. 50 (N.D. Calif. 1969), remanded on other grounds, 401 U.S. 254, 3 SSLR 3737 (1971).

17 There are no such provisions in the regulations, and the registrant possesses no power to subpoena them. Nor are there any cases giving the registrant such a right. See generally Comment, The Selective Service System: An Administrative Obstacle Course, 54 Calr. L. REv. 2122 (1966).

18 Prior to the 1971 Act, no such right existed at any level. Their admission was discretionary with the local board. United States v. Evans, 425 F.2d 302, 2 SSLR 3668 (9th Cir. 1970). New Reg. § 1626(d) still bars witnesses from appearing before the appeal board.

19 See United States v. Wood, 454 F.2d 765, 5 SSLR 3163 (4th Cir. 1972); SSLR PRAcricE Manual If 1080, at 1065 (1968).

20 New Reg. \& I626.4(e) allows the registrant to present to the appeal board arguments about information that the local board may have overlooked. But there is no provision for verbal interchange with the appeal board by which the registrant may determine what factors the board believes crucial so that he may attempt to address these problems. 
that may have substantially less impact on an individual's life. Other cases dealing with procedural safeguards in adjudicatory determinations may be examined for guidance in determining what rights the standards of due process usually require. ${ }^{21}$

In Goldberg $v$. Kelly, ${ }^{22}$ a case involving the termination of welfare benefits, the Supreme Court ruled that the benefits could not be terminated until the recipient had been afforded a hearing "at a meaningful time and in a meaningful manner." 23 For this hearing to be meaningful, the Court said, the recipient had to be afforded the rights to be represented by counsel, to introduce witnesses on his own behalf, to confront and to cross-examine witnesses against him, to have a record of the hearing, and to hear the reasons and evidence relied on by the decision maker. These procedural safeguards are those normally afforded in a judicial hearing. Although in some administrative proceedings fewer safeguards are required than in this judicial model, ${ }^{24}$ the minimum standards enumerated in Goldberg have been applied to a wide variety of other administrative actions: entrance to and expulsion from public housing, ${ }^{25}$ denial of student status, ${ }^{26}$ withdrawal of a license to transact business, ${ }^{27}$ withdrawal of security clearance, ${ }^{28}$ deportation proceedings, ${ }^{29}$ revocation of parole, ${ }^{30}$ and dismissal from public employment. ${ }^{11}$ Moreover, these safeguards protect the interests of the

21 See United States v. Weller, 309 F. Supp. 50 (N.D. Cal. 1969), remanded on jurisdictional grounds, 401 U.S. 254 (1971); cf. Philadelphia Co. v. SEC, 175 F.2d 808 (D.C. Gir. 1948), appeal dismissed as moot, 337 U.S. 901 (1949). See also I K.C. DAvis, supra note II, I 7.04 (1958, 1970 Supp.); Davis, An Approach to Problems of Evidence in the Administrative Process, 55 HARv. L. REv. 364 (1942). At least one law review note develops the analogy to other adjudicatory situations. Note, supra note 16 , at 484-86. But see United States v. Evans, 425 F.2d 302, 2 SSLR 3668 (9th Gir. 1970), and cases cited therein.

22397 U.S. 254 (1970); cf. Hansen, supra note 11, at 465.

23397 U.S. 254, 267 (1970).

24 An example is proceedings that are merely investigatory. Hannah v. Larche, 363 U.S. 420 (1960); see Newman, The Process of Prescribing "Due Process," 49 CALIF. L. REv. 215 (1961).

25 Escalera v. New York City Housing Authority, 425 F.2d 853 (2d Cir. 1970); Holmes v. New York Housing Authority, 398 F.2d 262 (2d Cir. 1968); Williams v. White Plains Fousing Authority, 62 Misc. 2d 613 (Sup. Ct. 1970).

26 Dixon 7. Alabama State Bd. of Educ., 294 F.2d 150 (5th Cir. 1961), cert. denied 368 U.S. 990 (1962).

27 Schware v. Board of Bar Examiners, 353 U.S. 232 (1957); Goldsmith v. United States Bd. of Tax Appeals, 270 U.S. 117 (1926).

28 Greene v. McElroy, 360 U.S. 474 (1959); cf. Parker v. Lester, 112 F. Supp. 433, 443 (N.D. Cal. 1953), rev'd, 227 F.2d 708 (9th Cir. 1955).

29 Bridges v. Wixon, 326 U.S. 135 (1945); Ng Fung Ho v. White, 259 U.S. 276 (1922).

80 United States ex rel. Bey v. Connecticut Board of Parole, 443 F.2d 1079 (2d Cir. 1971). The majority position is the opposite, however. Hyser v. Reed, 318 F.2d 225 (D.C. Cir.), cert. denied, 875 U.S. 957 (1963).

81 See Vitarelli v. United States, 359 U.S. 535 (1959). 
government as well as the individual. They facilitate appropriate classification in conformity with congressional intent.

The absence of procedural safeguards in appeal board determinations engenders opportunities for error and abuse. The existence of unpaid ${ }^{32}$ and inexpert ${ }^{33}$ boards, overloaded with work, ${ }^{34}$ no doubt causes many errors prejudicial to the registrant. There is evidence that cases are rushed through without the required de novo review ${ }^{35}$ and that incorrect standards are often applied to the facts. ${ }^{36}$ The importance of the appeal board in its procedural context, coupled with the absence of customary safeguards and the evidence of a significant quantum of error, calls for a critical reexamination of the traditional due process balance in Selective Service Cases.

\section{Due Process and the Appeal Boards-A General Balance}

In the early development of the Selective Service case law, courts were reluctant to hold that the due process clause applied to determinations made by draft boards. ${ }^{37}$ Review could be obtained only by habeas corpus after induction, and then only if the Selective Service had failed to follow the procedures it had prescribed for itself..$^{38}$ Because the draft constitutes direct governmental action by which persons may be deprived of their liberty, courts have since recognized that Selective Service

32 Old Reg. $\S 1603.3$. New Reg. $\S 1603.3$ appears to leave open the possibility that appeal board members might be paid.

33 The members are drawn from the general public and need possess no special knowledge. New Reg. \& 1604.22. Old Reg. § 1604.22 specified that the board consist of one member each from labor, industry, and agriculture and a lawyer and a physician. See Tigar \&: Zweben, Selective Service: Some Certain Problems and Some Tentative Answers, 37 GEo. WASH. L. REV. 510, 527 (1969).

34 See text and notes at notes 85-89 infra.

35 See notes 115-122 infra; of. United States v. Mantione, - F. Supp. -, 5 SSLR 3085 (S.D.N.Y. 1972); Senate Hearings, supra note 9, at 62, 153; Shattuck, Record Keeping Obligations of Local Boards, 1 SSLR 4015, 4018-9 (1968); White, Processing Conscientious Objector Claims: A Constitutional Inquiry, 56 CALrF. L. REv. 652, 673 (1968); Comment, supra note 17, at 2158; Note, 1971 Wxsc. L. REv. 318, 327.

36 Some irregularity is obviously shown by the fact that not all Selective Service prosecutions result in convictions. See SSLR 6003 (1971); 4 SSLR 70 (1971). There has also been one statistical study disclosing the extent to which illegal standards are applied by appeal boards. Reisner, supra note 12, reports on a survey of 272 actual cases on appeal. As one example, while 13.5 percent of all claimants received 1-0 status, of the 82 who failed to claim an affiliation with an organized religion, not one received a 1-0, even though all relevant court decisions hold that such affiliation is irrelevant to the conscientious objector claim.

37 Gen. Louis B. Hershey supported the thesis that "it doesn't matter how fair it is," as long as it "gets the men." Comment, 44 NOTRE DAME LAW. 469, 474 (1969).

38 Compare Dickinson v. United States, 346 U.S. 389 (1953), and Estep v. United States, 327 U.S. 114 (1946), with Falbo v. United States, 320 U.S. 549 (1944); Koch v. United States, 150 F.2d 762 (4th Cir. 1945); United States v. Rinko, I47 F.2d 1 (7th Cir. 1945); and United States v. Pitt, 144 F.2d 169, 173 (3d Cir. 1944). 
procedures must conform to the requirements of due process. ${ }^{39}$ The courts have, however, interpreted due process as applied to the Selective Service appeal boards to consist solely of the right to a full and fair hearing, or to a "meaningful appeal." 40 Moreover, courts have been reluctant to insure that the specific safeguards that make a full and fair hearing possible (or likely) are actually employed.

Courts have invariably decided questions of due process in Selective Service proceedings by balancing the interests of the individual against those of national security. In performing this task, they have come to a position strongly weighted in favor of national security claims. ${ }^{41} \mathrm{~A}$ characteristic example is United States $v$. Nugent. ${ }^{42}$ That decision upheld a refusal to disclose to the registrant the contents of an FBI report on his character and background that was to be used by the Department of Justice hearing examiner in determining whether to recommend him for conscientious objector status. Although the court acknowledged that due process required that the registrant be given a "fair opportunity to ... speak his piece" 43 at the hearing and that ignorance of the contents of the report might frustrate this right, it held the expeditious processing of draft cases to be sufficient reason for denying the registrant any right that might entail even a short delay in his processing: ${ }^{44}$

In this and other opinions, courts have made certain unexamined assumptions about the needs of national security and the interests of the individual. The exposition of these assumptions, and an examination of their validity, is necessary if a correct balance is to be struck.

\section{A. The National Security Interest}

Behind the consistent denial of procedural safeguards on the ground of national security, ${ }^{45}$ lie three separate assumptions: (1) in order to in-

39 See Simmons v. United States, 348 U.S. 397 (1955); United States v. Nugent, 346 U.S. I (1953). Contra, United States v. Mientke, 387 F.2d 1009 (7th Gir. 1966), cert. denied, 390 U.S. 1011 (1967).

40 Estep v. United States, 327 U.S. 114, 127 (1946) (Murphy, J., concurring); see Gutknecht v. United States, 396 U.S. 295, 2 SSLR 3367 (1970); Simmons v. United States, 348 U.S. 397, 404 (1955); United States v. Nugent, 346 U.S. I, 6 (1953). See generally Sedler, supra note 11; Comment, supra note 17; Comment, supra note 11 .

41 Normally, the court will simply recite that rapid processing is necessary in the interest of national defense. The cases collected in note 16 supra on the denial of counsel provide excellent examples of this. Such cases as United States v. Evans, 425 F.2d 302, 2 SSLR 3668 (9th Cir. 1970), also demonstrate the propensity of courts to dismiss the interest of the registrant merely because the proceeding is administrative, without examining the nature of that interest at all. See cases cited note 66 infra; Senate Hearings, supra note 9, at 95.

42346 U.S. 1 (1953).

$43 \mathrm{Id}$. at 6.

$4 \pm$ Id. at 10 .

45 See H.R. REP. No. 92-493, 92d Cong., Ist Sess. (1971) (Conference Committee Report 
duct large numbers of men, the Selective Service must be able to process each case quickly; (2) procedural safeguards will slow this processing unacceptably; (3) the demand for rapid processing does not vary but remains constant in both wartime and peacetime. All three of these assumptions are unwarranted.

1. Must Each Case be Processed Quickly? To answer this question, two situations must be distinguished: the case of rapid mobilization and the case of constant high demand for inductees. ${ }^{46}$ When rapid mobilization is required, the stock of persons utilized are only those with a final 1-A classification. Those who are not $1-\mathrm{A}$, or whose classifications are being appealed, will not be available for a length of time. The appeal process is already so lengthy that persons involved in it are unreachable for induction for several months. ${ }^{47}$ Those not classified 1-A must be reclassified $\mathrm{I}-\mathrm{A}$ and will have the opportunity to create delay by taking appeals. Thus, the size of the 1-A pool that has been maintained, and not the marginal increase in processing time that safeguards might cause, will be critical during mobilization. Moreover, the Selective Service System has recently taken steps to decrease the size of the 1-A pool in order to reduce administrative costs. ${ }^{48}$ This suggests that the military may no longer consider rapid mobilization to be a real or important possibility.

Similarly, there is also no need for rapid processing of individuals when calls are constantly high since in the long run the number of men available for induction will not be affected by the length of time it takes to process them to 1-A status. Individual delays in processing can increase the average age of the inductees, but they cannot affect the number of inductees available. It is possible that affording more pro-

on the $1971 \mathrm{Act}$ ); Sedler, supra note 11, at 1141; Comment, supra note 17, at 2145; Note, The New Draft Law: Its Failures and Future, 19 CAsE W. REs. I. REv. 292, 319-20 (1968).

46 A third possible case, a situation in which there is slight and constant demand for inductees, obviously does not require rapid processing of any sort.

47 New Reg. $\S \S 1624,1626$ provide for a series of appeal board actions and registrant responses, each of which may take a month. In addition, if the registrant misses a meeting for cause, it may be rescheduled. It has become standard practice among draft counselors to count on the availability of a delay of at least four months. A registrant will take even longer to be reclassified out of $\mathbf{1 - H}$ since no information is gathered on him while he is in the holding category, and a series of questionnaires and a physical examination may have to be added to delays resulting from appearances and appeals.

48 New Reg. $\$ \S 1622.18,1624.1$ (a), 1626.1. Registrants unlikely to be called under current call rates are classified $1-\mathrm{H}$. Before they may be called during a mobilization, they must be reclassified I-A, and all rights of appearance and appeal again become available to them. The 1-H category was created to ease the work load of the Selective Service by virtually deactivating large numbers of files, indicating that the Service values its own current administrative convenience more than the need for haste in possible future mobilization. 
cedural safeguards would result in more deferments, thus reducing the number of men available for induction. But any objection to such a reduction is a quarrel not with the safeguards themselves, but with the congressional policy regarding deferments; the remedy lies in a changed deferment structure, not in a paucity of safeguards. Ultimately, the flexible nature of the draft structure eliminates the danger that procedural safeguards would necessarily impede meeting military demands. When the demand for men is great, Congress reduces the number of available deferments and makes the substantive criteria for obtaining them more restrictive than during times of low demand. ${ }^{49}$

That the system can tolerate lengthy processing procedures for a substantial number of inductees is shown by the willingness of Congress to continue through three wars the system by which the Department of Justice investigated and made recommendations regarding conscientious objector applicants. ${ }^{50}$ Each investigation consumed eight months to a year, and the number of such investigations was substantial, although less than one percent of all registrants. ${ }^{51}$ The point is simply that there is leeway in the Selective Service System for many registrants to be permitted long delays in processing without jeopardizing the national security interest. Each case need not be processed quickly. ${ }^{52}$

2. Would Safeguards Slow Processing? Awarding additional procedural safeguards would not necessarily increase the length of the appeal board proceedings. A recent Selective Service regulation announced a fifteen-minute limit on the length of a personal appearance before the local board.53 Presumably, this limitation could be retained whether or not a lawyer were allowed to be present. In fact, safeguards might also produce some time savings. An attorney might, if allowed to be

49 During World War II, there were few deferments. The only one possessed by any considerable number of men was that of a worker in an essential industry. The stringent criteria for hardship and physical deferments or exemptions made them almost impossible to acquire.

50 For the details of the procedure, see text and notes at notes 134-38 infra. It was terminated for budgetary reasons when the 1967 Act was passed, but had been in effect during World War II and the Korean and Vietnamese conflicts.

51 See 1942 SEL. SERv. ANN. REp. 255-61. The number rose steadily throughout World War II. 1945 SEL. SERv. ANN. REP. 179, 332.

82 In the wake of the new procedural rights granted by Congress in the 1971 Act, at least one court has shown an increased willingness to tolerate some delays in processing even beyond those specifically authorized by Congress:

We need hardly concern ourselves further about the inconvenience to the Selective Service System which may be caused by the courts which insist upon administrative due process. Congress has in Section 22 gone much further than the courts have heretofore seen fit to go.

United States ex rel. Bent v. Laird, 453 F.2d 625, 4 SSLR 3739, 3743 (8d Cir. 1971).

53 New Reg. § 1624.4(c). 
present before the local board or the appeal board, help to curtail procedural and legal errors that lengthen processing time by necessitating time-consuming appeals or trials. Other rights, such as access to a transcript, could be provided without creating significant delay..$^{54}$

The argument is sometimes advanced that safeguards must be avoided since, if all registrants exercised all of their rights, the system could be brought to a halt. ${ }^{55}$ As a practical matter, however, all registrants do not use all of their present rights. A very small percentage of registrants appeal from an adverse classification. ${ }^{56}$ Certainly, procedures that work well under usual circumstances should not be precluded merely because of an extremely remote possibility of an extraordinary circumstance.

Even if substantial numbers of registrants took advantage of new and enlarged procedural safeguards, the processing of appeals could still be maintained at any necessary or desired rate by the addition of more personnel to the administrative structure. Appeal board members are volunteers, and staff requirements are not heavy, so that an increase in personnel would not be unbearably costly. ${ }^{57}$ Seen in this light, the question is not whether the national security should be sacrificed to afford individual rights, but whether staff requirements should be increased to achieve this result.

Moreover, the military itself provides the model for the preservation of due process rights through adequate staffing. ${ }^{58}$ When a serviceman applies for an in-service conscientious objector discharge, he is assigned, if possible, to duties consistent with his asserted beliefs, and he is

54 The only delay involved is the time required to set up a tape recorder at the beginning of each board session and to change tapes as they run out.

55 This premise underlies all of the arguments that speed is necessary to protect the national security, but it is often made explicitly as well. See Senate Hearings, supra note 9, at 95 .

66 1971 Ser. Serv. Semiann. Rep. 53; National Advisory Comm'n on Selective Service, IN Pursutt of Equity: Who Serves Wren Not Alc Serve 28, 110 (1967) [hereinafter cited as MARShaLL REPORT].

57 There are approximately one hundred appeal boards in the country. Marshall Report, supra note 56, at 110-11. To expand this number would not require substantial additional staff since the current staff already handles all the paperwork. Additional board members are costless since they are volunteers. Thus, only creation of the new boards in new geographic locations would bring about any substantial increase in costs.

58 The procedures are set forth in Department of Defense Directive 1300.6, SSLR 2325 (Aug. 20, 1971). See generally Hansen, Judicial Review of In-Service Conscientious Objector Claims, 17 U.C.L.A.L. REv. 975 (1970). It should be noted that these rights are provided even though few would argue that the serviceman has a "right" to a conscientious objector discharge, but that being classified 1- $O$ under Selective Service is a mere "privilege." Logically, either both are rights or neither is. If a distinction can be made at all, the in-service case looks even more like a privilege. Holdings that in-service safeguards are required by due process are not uncommon. Robin v. Secretary of the Army, - F. Supp. 一, 4 SSLR 3508 (D.D.C. 1971); Hansen, supra. 
interviewed by a chaplain, a psychiatrist, and a hearing officer. Before the hearing officer, he may be accompanied by counsel, introduce witnesses, cross-examine adverse witnesses, and make a transcript of the proceedings. The hearing officer must furnish recommendations and reasons therefor, to which the serviceman may reply. The hearing officer's report is forwarded to the legal staff, which conducts a review for completeness and legal sufficiency. A final decision on the case is then made by the headquarters of the military service involved, which must render an opinion and allow the serviceman to inspect and to reply to any additional information on which it relies. Final review may be had by habeas corpus. ${ }^{59} \mathrm{It}$ is difficult to see how granting similar safeguards outside the military would harm the national security more than granting them within, provided that staffing is sufficient to prevent unnecessary delay.

3. Is Rapid Processing Always Required? If, as suggested above, rapid processing of every individual is not necessary to the national security and safeguards do not appreciably slow processing, then safeguards should be afforded even during time of war. During time of peace, the argument is even more compelling since in such periods the national security interest should be accorded far less weight in the balancing process. Indeed, since only the importance of the national security interest justifies the denial of procedural safeguards, a case can be made independently that during times of relative tranquility individual rights should regain their dominance. Yet to date no court has made this sensible distinction. ${ }^{60}$ There is precedent for it in the expansive powers the President possesses during wartime. Further, as the language of Goldberg $v$. Kelly $y^{01}$ suggests, the balance of individual rights versus governmental need is a temporal one and will change when appropriate to meet changing needs. ${ }^{62}$

The existence of safeguards during peacetime would in no way impede the Selective Service from raising an army rapidly during a mobilization. As has already been shown, the mobilization depends on the size of the 1-A pool and not on the availability of safeguards. By the

50 This sometimes raises complex jurisdictional problems. Schlanger v. Seamans, 401 U.S. 487, 3 SSLR 3753 (1971); Hansen, The Jurisdictional Bases of Federal Court Review of Denials of Administrative Discharges from the Military, 3 SSLR 4001, 4 SSLR 4001 (1971).

60 The reason for the failure to make such a distinction is no doubt the assumption that Selective Service must be able to process everyone quickiy should a mobilization be required.

61397 U.S. 254, 265-66 (1970).

62 Similarly, the doctrine of prior restraints on publication may vary with the nature of the material and its relation to the war status of the United States, See New York Times v. United States, 403 U.S. 713 (1971). 
time the 1-A pool has been exhausted, enough time will have elapsed for Congress to tailor the procedural safeguards and the classification structure to the needs at hand. ${ }^{63} \mathrm{~A}$ distinction between rights during war and rights during peace is both appropriate and necessary and has received the approval of Justice Frankfurter in another context: "The enemy is not yet so near the gate that we should allow allow respect for traditions of fairness, which has heretofore prevailed in this country, to be overborne by military exigencies." 64

\section{B. The Individual's Interest}

The weight assigned by courts to the individual interests involved in Selective Service adjudication has normally been slight. ${ }^{65}$ Courts have answered the contentions of registrants with two general assertions: First, that since the Selective Service is an administrative agency, the registrant must settle for few safeguards, ${ }^{66}$ and second, that no registrant is entitled to any deferment except as a privilege granted by Congress. ${ }^{67}$ Neither assertion confronts the critical issues. Many other administrative proceedings are attended by full judicial safeguards. ${ }^{68}$ Clearly, what is critical to due process is not the verbal category in which the proceeding is put, but the nature of the underlying interests. ${ }^{69}$ Similarly, the privilege doctrine merely denotes that category of things the court has decided not to protect. The particular origin of the underlying rights is not determinative since Congress can create both "privileges" and

63 During World War II, for example, men up to age forty-five were required to register. During 1942, about two-thirds of all those of age were liable; of the 14 million not liable, 13 million were in essential occupations and the rest physically unfit or deferred for extreme hardship. 1942 SEL. SERV. ANN. REP. 10. The advent of the Vietnamese conflict saw student deferment criteria tightened and marriage and paternity deferments ended. But still, during the height of the conflict, of 33 million registrants only 1 million were available for induction. 1968 SEL. SERV. SEMTANN. REP. 4. Nineteen seventy-one was marked by further diminution of deferments, but this seems to reflect a new striving for equity rather than any attempt to increase the number available for induction.

64 United States v. Nugent, 346 U.S. 1, 13 (Frankfurter, J., dissenting).

65 E.g., United States v. Sturgis, 342 F.2d 328 (3d Gir. 1965).

66 E.g., United States v. Evans, 425 F.2d 302, 2 SSLR 3668 (9th Cir. 1970); United States v. Mientke, 387 F.2d 1009 (7th Cir. 1967), cert. denied, 390 U.S. 1011 (1967).

67 E.g., Haven v. United States, 403 F.2d 384, 1 SSLR 3269 (9th Gir. 1968), cert. denied, 393 U.S. 1114 (1969); Salamy v. United States, 379 F.2d 838, 841 (10th Cir. 1967); Storey v. United States, 370 F.2d 255 (9th Cir. 1966); Senate Hearings, supra note 9, at 91; Comment, supra note 11.

68 See cases cited notes 22-31 supra.

69 This is the standard framework within which due process arguments are made. See Goldberg v. Kelly, 397 U.S. 254 (1970); Hannah v. Larche, 363 U.S. 420 (1960); Greene v. McElroy, 360 U.S. 474 (1959); Shaughnessy v. United States ex rel. Mezei, 345 U.S. 206 (1953) (Black, Douglas, Jackson, and Frankfurter, JJ., dissenting); Parker v. Lester, 112 F. Supp. 433 (N.D. Cal. 1953), rev'd on other grounds, 227 F.2d 708 (9th Cir. 1955). 
"rights."70 Again, it is the nature of the underlying interest that is determinative. This point was emphasized in Goldberg $v . K_{\text {Kelly, }}{ }^{71}$ in which the Court held that due process safeguards apply to the withdrawal of welfare benefits, even though welfare benefits had always been termed a privilege. The Court found that due process safeguards must be afforded when an individual may be "condemned to suffer grievous loss"72 if a benefit is withdrawn. Draft deferments would seem to qualify under this rule.

The interest of the registrant may be divided into two components: the potential for individual hardship should a particular proceeding result in a miscarriage of justice and the availability of effective review of that proceeding. Courts characteristically respond cryptically to these components, noting that "the appeal board is not a criminal proceeding," that it does not actually induct the registrant, or that judicial review is always available. ${ }^{73}$ Presumably, the procedural safeguards lacking before the appeal board will be provided in the courtroom.

Although the appeal board proceeding is not technically a criminal proceeding, an adverse determination by the appeal board has a substantially similar result. Review of its factual determinations and discretionary actions in any civil preinduction proceeding is expressly barred by the Act. ${ }^{74}$ Although some exceptions to that bar have been created, they reach only "blatant lawlessness" in the procedure of the board. Direct review of a Selective Service decision before induction is therefore usually available only in a criminal prosecution. If the registrant accepts induction, he may have review of his classification by

70 See I K.C. Davis, supra note 11, If 7 (1958, 1970 Supp.).

71397 U.S. 254 (1970). Many of the cases at notes 24-31 supra also represent privileges that have been turned into rights. Cf. Oestereich v. Selective Serv. Sys. Local Bd. No. 11, 393 U.S. 233, I SSLR 3215 (1968) (4-D status held to be a right).

72397 U.S. at $262-63$.

73 Cases denying the registrant the right to have a lawyer present, cited note 16 supra, are an example.

741967 Act $\S 460(\mathrm{~b})$ provides that all Selective Service determinations shall be final, thus precluding preinduction review. The courts have made some inroads against this preclusion, and review will sometimes be granted when the appeal board has denied the registrant a statutory right or utilized a procedure that is blatantly lawless. No action is reviewable if it is discretionary on the part of the board, however, and therefore classification decisions made within procedures that are not blatantly lawless are immune from preinduction attack. Fein v. Selective Serv. Sys. Local Bd. No. 7, 92 S. Ct. 1062, 5 SSLR 3207 (1972); Breen v. Selective Serv. Sys. Local Bd. No. 16, 396 U.S. 460,2 SSLR 3373 (1970); Clark v. Gabriel, 393 U.S. 256, 1 SSLR 3220 (1968); Oestereich v. Selective Serv. Sys. Local Bd. No. 11, 393 U.S. 233, 1 SSLR 3215 (1968); Winick, Direct Judicial Review of the Actions of the Selective Service System, 69 Mich. L. REv. 55 (1970); O'Neil, Review of Selective Service Reclassifications, 37 GEo. WASH. L. REv. 596 (1969); Comment, The Expanded Availability of Preinduction Judicial Review, 44 TEMP. L.Q. 127 (1970). 
habeas corpus, ${ }^{75}$ but then he is subject to the military command in the interim and after an adverse decision; additionally, the standard for review of the Selective Service decision is the same as that in the criminal prosecution. In the prosecution of habeas corpus proceedings, the registrant is accorded the traditional due process safeguards. But this day in court hardly provides an adequate opportunity for challenging his classification. All the Government need prove to secure conviction or defeat habeas corpus is that there was an induction order outstanding. The registrant must affirmatively prove that this induction order was issued illegally. ${ }^{76}$ As noted previously, however, the juxtaposition of the presumption of regularity and the secrecy of the proceedings severely limits the potential for effective review. ${ }^{77}$ Moreover, the order is challengable only on the ground that no basis in fact for it existed. This narrow standard of review results in judicial deference to any board decision absent the most flagrant abuse of discretion. The severe effect of this standard is accentuated by the criminal penalty involved. The normal standard of "innocent unless proven guilty beyond a reasonable doubt" is effectively reversed to "guilty unless there is no basis in fact for guilt." 78

If the appeal board denies his claim, the registrant is therefore faced with either the loss of his liberty through induction or the probability of imprisonment. In re Gault ${ }^{79}$ has established that even when a juvenile is faced with a short penalty in a technically noncriminal proceeding, the standard due process safeguards are necessary. The same reasoning would seem to apply to appeal board decisions.

The only solution to the inequities of the present system lies in recognizing the fact that the appeal board makes factual determinations critical to conviction and in providing safeguards accordingly. The full import of the appeal board decision and the individual stake in

75 See United States v. Eisdorfer, 299 F. Supp. 975, 2 SSLR 3002 (E.D.N.Y.), cert. granted, 396 U.S. 884, appeal dismissed, 396 U.S. 1066 (1969); cf. Gutknecht v. United States, 396 U.S. 295, 2 SSLR 3367 (1970); Eagles v. United States ex rel. Samuels, 329 U.S. 304 (1946); Bridges v. Wixon, 326 U.S. 135, 150, 163 (1945).

76 See SSLR PRActice MANuAL If 2002-05 (1968).

77 See text and notes at notes 6-21 supra.

78 See Estep v. United States, 327 U.S. 114 (1946), and subsequent cases applying the basis-in-fact test.

79387 U.S. 1 (1967). The analogy to Gault is often made in other Selective Service contexts, always to point out that a serious interest and potential penalty is deserving of procedural safeguards. See United States v. Weller, 309 F. Supp. 50, 2 SSLR 3229 (N.D. Cal. 1969), vacated and remanded on jurisdictional grounds, 401 U.S. 254, 3 SSLR 3737 (1971); United States v. St. Clair, 293 F. Supp. 337, 1 SSLR 3224 (E.D.N.Y. 1968); Note, supra note 35, at 327. Contra, United States v. Holmes, 387 F.2d 781, 785 (7th Cir.), cert. denied (with opinion), 391 U.S. 936, I SSLR 3084 (1967). 
the controversy should be weighed in the due process balance. ${ }^{80}$ The resolution of that balance in specific problems raised by the appeal board proceeding may now be considered.

\section{Due Process and the Appear Boards-A Specifrc Balance}

Perhaps the right that has received the most attention in the commentary is the right to be accompanied by counsel before the boards. ${ }^{81}$ This right has been conclusively rejected by the courts and will not be dealt with here. ${ }^{82}$ Some other basic rights, such as the right to introduce witnesses on one's own behalf, have been granted at the local board but not the appeal board level. ${ }^{83} \mathrm{~A}$ convincing case can be made that the registrant is entitled to the same rights before the appeal board, which is charged with making a de novo review, that he possesses in relation to the local board. There is a growing body of cases so holding, although none of them yet deals with the right to introduce witnesses. ${ }^{84}$ Such an extension would seem to be logical. Other problems, which seem to be particular to or more important in the appeal board context, are discussed next.

\section{A. The Right to a Full and Fair Hearing-Due Process and Ad- ministrative Overload.}

There is extensive evidence that the appeal boards are swamped with work. Appeal board members are volunteers who meet for short periods of time-typically three or four hours-once or twice per month. In these short meetings, the boards have many cases to decide. The National Advisory Commission on Selective Service found in 1967 that caseloads for a single board ran as high as 3,000 cases per year; ${ }^{85}$ the number of appeals has increased since then..$^{86}$ One appeal board decided 867 cases in a two-hour meeting. ${ }^{87}$ This overload has been admitted

80 See Olvera v. United States, 223 F.2d 880 (5th Cir. 1955); Comment, supra note 17; Comment, supra note 11. It might also be argued that a difference exists in the weight of this argument between wartime and peacetime. It is less important to be objectively "fair" when selecting the few who will not go during wartime than in selecting those who will be required to bear an extraordinary burden shared by few of their fellow citizens.

81 See cases and discussions summarized in Comment, supra note 11; Note, supra note 16.

82 See note 16 supra.

83 New Reg. §§ 1624, 1626.

84 E.g., United States v. Stetter, 445 F.2d 472, 4 SSLR 3199 (5th Cir. 1971); United States v. Crownfield, 439 F.2d 839, 3 SSLR 3833 (3d Cir. 1971); United States v. Kember, 437 F.2d 534, 3 SSLR 3539 (9th Cir. 1970), cert. denied, 402 U.S. 912 (1971).

85 MARShaLl RePORT, supra note 58, at 28.

80 See 1968-71 Sel. Serv. SemLann. ReP.; cf. Ginger, Minimum Due Process Standards in Selective Service Cases I, 19 HAstings L.J. 1313, 1324 (1968); Sedler, supra note 11, at 1189.

87 Margolis, Trying a Case Under the Selective Service Law, 26 Guild Practrrioner 100, 103 (1967). 
by Selective Service officials in congressional testimony, ${ }^{88}$ although exact data on individual boards have been kept secret. In some cases involving judicial challenges to appeal board decisions, average times of less than thirty seconds per appeal have been revealed. ${ }^{89}$

Such summary proceedings arguably violate Selective Service regulations, ${ }^{90}$ but the need for reform goes beyond the simple demand that regulations be meticulously followed. ${ }^{91}$ A minimum due process requirement was established in Morgan $v$. United States, ${ }^{92}$ in which the Supreme Court held that the "official" decision maker must at least be sufficiently involved with the actual decision to know what he is approving..$^{93}$ This standard alone calls into serious question the validity of some appeal board decisions. Beyond that, however, the Supreme Court cases have gone no further than to assert repeatedly the need for the Selective Service to provide procedural fairness. ${ }^{94}$ It remains necessary to give specific content to that requirement in the context of procedural overload. This will be aproached in two ways: (1) by dealing with the overload itself and (2) by dealing with the file resume, one method by which the Selective Service has attempted to meet the problem.

1. The Abridged Hearing. There are several cases dealing with the problem of overload in which contentions of denial of a full and fair

88 Senate Hearings, supra note 9, at 245; cf. Hearings on Selective Service and Military Compensation Before the Senate Comm. on Armed Services, 92d Cong., 1st Sess. 339 (1971). 89 See cases cited notes 102-11 infra.

90 The abridged appeal procedures apparently violate Reg. $\S 1626$, which requires the appeal board to examine fully and independently each file and to decide the case on the basis of all the evidence, and Old Reg. $\S 1604.22$, which required state directors to appoint new panels whenever the caseload became too great for existing panels to handle. $C f$. Mulloy v. United States, 398 U.S. 410, 416 (1970) ("[b]ecause of the narrowly limited scope of judicial review available to a registrant, the opportunity for full administrative review is indispensible to the operation of the Selective Service System"); Sedler, supra note 11, at $1149,1188-91$.

91 This principle that, when every requirement of due process has been observed by the board, its fact decisions, unless wholly unsupported, are not subject to review, makes it certain that [the board must follow Selective Service regulations]. Under this principle, it is the essence of the validity of board orders and of the crime of disobeying them that all procedural requirements be strictly and faithfully followed, and a showing of failure to follow them with such strictness and fidelity will invalidate the order of the board and a conviction based thereon.

Olvera v. United States, 223 F.2d 880, 881 (5th Cir. 1955). The possibilities for this defense of failure to follow procedure and details of the way in which it is raised are fully explored in Sedler, supra note 11.

92298 U.S. 468 (1936); 304 U.S. 1 (1938).

93 $C f$. Reg. §§ 1626.23-24. The behavior that Morgan condemned may be even more excusable than the Selective Service situation since the decision maker in Morgan had a power to subdelegate that the appeal board lacks.

94 See cases cited note 40 supra. 
hearing are dismissed, almost without discussion. In one Ninth Circuit case, the entire relevant portion of the opinion is as follows:

Appellant complains of the large number of appeals decided by the appeal board in a relatively short period of time. The record is completely devoid of evidence on the nature of the other matters considered by the appeal board or the time devoted to an evaluation of appellant's appeal. In these circumstances, we are required to assume that the appeal board considered all pertinent material in appellant's file. ... This presumption of regularity has been recognized and applied by us to both local and appeal board actions.95

The court may have been unaware of the difficulty of presenting to it any other evidence of the appeal board proceedings. The court may also have relied on the nature of the material in the registrant's file or assumed that the registrant's claim was given a full hearing with time saved from the speedy processing of "frivolous" claims. The opinion does not discuss these possibilities. But if the decision is taken at face value, this use of the presumption of regularity to dismiss due process claims is particularly objectionable since the evidence needed to rebut the presumption is simply unavailable. To reject the sort of circumstantial evidence the registrant presented is to insulate the appeal board from almost all challenges. ${ }^{96}$

Challenges to short appeals have met with two other types of rebuff from the courts. The first is an assertion that average length of appeal can never be a useful piece of evidence. One court stated, for example:

$[T]$ here is no way to determine from the record how much time was spent on any single case. It is idle to try the due process question on the basis of whether the Board spent 15 seconds or 15 minutes on the defendant's claim. The secretary of the Local Board testified that she could not recall how much time was spent on it, but she did confirm that the matter was considered and recorded in the files in the regular course of business. This . . . is as much as the defendant is entitled to, insofar as due process is concerned. ${ }^{97}$

o5 United States v. Neckels, 451 F.2d 709, 4 SSLR 3713 (9th Gir. 1971) (citations omitted). Accord, United States v. Kember, 437 F.2d 534, 3 SSLR 3539 (9th Gir. 1970), cert. denied, 402 U.S. 912 (1971). The only knowledge of the claim in Kember is from the brief filed in support of a request for certiorari. The average appeal before Kember's appeal board was apparently thirty-five seconds. The court dismissed the claim, stating: "Kember does not present any authority in support of his other contentions on this branch of the case. We are satisfied that he was not deprived of due process of law in the respects described." Id. at 538, 3 SSLR at 3540 .

96 For the kinds of available information on appeal board behavior, see notes 7-12 supra.

97 United States v. Losczyk, - F. Supp. - 4 SSLR 3766 (N.D. Ill. 1971); accord, United States v. Brown, 338 F. Supp. 409, 5 SSLR 3196 (N.D. Ill. 1972). 
The court appeared to assume that a consideration lasting but fifteen seconds would afford due process. It is difficult to believe, however, that any court could find that a consideration barely long enough to read the registrant's name and address can conform to due process. It is similarly not true, contrary to the court's assertion, that due process is always satisfied by a mere consideration and filing in the regular course, if that course provides no hearing at all. ${ }^{88}$

The second type of rebuff is found in Strople v. Local Board No. 60.99 The court, faced with a short average time for appeal board decisions, denominated that fact a mere "procedural irregularity." This, the court held, did not rise to the standard of "blatant lawlessness" in procedure required to make a case an appropriate one for judicial review before an induction order has been refused.100 Significantly, the court reserved the question whether the shortness of the appeal would be a sufficient defense to a criminal prosecution. The court also noted that it could not find the shortness of the appeal to be blatantly lawless since there was no precedent for such a decision. In that, it was simply mistaken. ${ }^{101}$

A better approach to the problem, adopted by numerous courts, is represented by the leading case of United States $v$. Wallen. ${ }^{102}$ The appeal board that had considered Wallen's claim for conscientious objector status had heard 122 claims at a two-hour meeting, an average of 59.01 seconds per case. The court referred to several other opinions that establish, in a general way, the right to a full and fair hearing on appeal, ${ }^{103}$ and went on to say:

It does not require lengthy argument to this court to convince that a 59 second appeal is not a meaningful appeal proceeding. It is almost a routine "rubber stamp" operation. . . . Such an appeal does not afford defendant the rights which Congress must have intended .... The proceeding is offensive to the concept of due process ......$^{104}$

98 See Gonzales v. United States, 348 U.S. 407 (1955).

99330 F. Supp. 187, 4 SSLR 3614 (E.D. Pa. 1971).

100 See Oestereich v. Selective Serv. Sys. Local Bd. No. 11, 393 U.S. 233, 237, 1 SSLR 3215, 3216 (1968). The court stated that the short appeal was not blatantly lawless since it was not in violation of a specific statutory command. That decision, if followed, would produce the curious result that it is blatant lawlessness to deny the registrant statutory rights, but mere irregularity to deny him constitutionally guaranteed rights.

101 See Slettehaugh v. Tarr, 322 F. Supp. 180, 4 SSLR 3106 (D. Minn. 1971).

102315 F. Supp. 459, 3 SSLR 3125 (D. Minn. 1970).

103 Bates v. United States, 348 U.S. 966 (1955); Gonzales v. United States, 348 U.S. 407 (1955); Mintz v. Howlett, 207 F.2d 758 (2d Gir. 1953); Gibson v. Reynolds, 172 F.2d 95 (8th Cir. 1949); Nevarez Bengoechea v. Micheli, 295 F. Supp. 257 (D.P.R. 1969); United States v. Zasadni, 206 F. Supp. 318 (W.D. Pa. 1962).

104315 F. Supp. 459, 460-61, 3 SSLR 3125, 3126 (D. Minn. 1970). 
The presumption of regularity was held contravened by the shortness of the appeal:

Even though other files may not be as thick as defendant's it seems to the court impossible that the board could have acted on any of the matters and cases before it in two hours with any detailed study or consideration. . . . To the extent that more than 59.01 seconds was spent [on defendant's file], less was of course spent on the other cases. ${ }^{105}$

The court also noted that it could not consider the Government's claim that the registrant was not entitled to the classification he sought and was therefore not prejudiced by the shortness of the appeal. The court answered that since it had no power to sit as a "super draft board," it could not determine whether the registrant was so entitled.

In several subsequent cases, courts have agreed with the holding in Wallen. In United States ex rel. Scott $v$. La France, ${ }^{106}$ the court expanded the scope of Wallen. The appeal board in Scott had heard 94 cases during a three-hour meeting, an average of about 2.5 minutes per case. The court had no trouble finding that due process had been denied the registrant. That brevity of appeal may satisfy the criterion of blatant lawlessness is demonstrated by Slettehaugh $v$. Tarr. ${ }^{107}$ There, the registrant's appeal board had heard 262 cases during its 285-minute meeting. The registrant's file contained 103 documents, 22 of which were directly relevant to his claim for a hardship deferment. The judge noted that it had taken him more than an hour just to read the file and therefore that the average time of 64 seconds during which the appeal board had to read the file and to consider and vote on the case was a violation of due process and so blatantly lawless as to make the case an appropriate one for preinduction review.

In all such cases, courts begin with the standard presumption of regularity. The issue in each case is what evidentiary showing the court will require to rebut that presumption and therefore to establish a prima facie case of irregularity. Once this showing of irregularity has been made, the burden falls on the appeal board to show that the particular registrant indeed received full consideration. In the usual case, the only evidence tending to show irregularity is the quantum of time spent by an appeal board per average appeal. To date, however, no court has ventured a general standard for using the quantum-of-time criterion.

Slettehaugh suggests that there is some time limit (perhaps as much

106 - F. Supp. - 4 SSLR 3493 (N.D. Ohio 1971); accord, United States v. Weaver, F. Supp. -, 5 SSLR 3286 (E.D. Pa. 1972).

107 822 F. Supp. 180, 4 SSLR 3106 (D. Minn. 1971). 
as ten minutes) beyond which the consideration will always be deemed sufficient, absent a showing by the registrant of special prejudice. ${ }^{108}$ Wallen and similar cases suggest, when taken together, that an average of two and one-half minutes will not suffice and that the presumption of regularity will be reversed if the record shows a lesser average. Since there are no cases currently in the four-to-ten-minute average, one can only speculate on courts' reactions to such fact situations. The minimum rule to be drawn from the cases, then, is that there will be a presumption of irregularity when the record shows an extremely short average appeal.

It is important to recognize that the Wallen test puts no undue burden on the Government. Where a fair hearing has in fact been granted to the registrant, the Government will have no difficulty in bearing the burden of proof, even in the context of a procedural overload. There are several ways in which the Government can prove that the registrant received full consideration.

In United States $v$. Woloszczuk, ${ }^{109}$ the registrant's claim had been one of 235 cases considered during a 210-minute meeting. The Government admitted that the registrant's claim for 4-D ministerial deferment presented some difficult problems for the board's consideration. The clerk testified, however, that such difficult claims were regularly given additional attention in the time "saved" from the summary disposition of frivolous appeals and that the registrant's claim in particular had received special attention. The registrant, who had been classified 1-A prior to his appeal, had requested 4-D. The appeal board changed his classification to 1-O. The court held that the evidence of special attention, together with the obvious fact that enough attention had been given to grant a classification different from that which the local board had granted, established that the appeal board had met the minimum standard of a full and fair hearing.

Similarly, a claim frivolous on its face would not be entitled to any specific length of time per average appeal. In United States $v$. Young, ${ }^{110}$ this procedure was implicitly adopted. The average time per appeal before the registrant's board had been forty-seven seconds. The registrant's claim, however, was for a 3-A fatherhood deferment, from which he was statutorily barred by virtue of his earlier possession of a 2-S

108 Although the ten-minute consideration in Slettehaugh was afforded by the local and not the appeal board, the basic question of what conclusion the courts will draw from length alone remains.

109328 F. Supp. 696, 4 SSLR 3557 (D. Mass. 1971); accord, United States v. Brown, 338 F. Supp. 409, 5 SSLR 3196 (N.D. Ill. 1972).

110324 F. Supp. 69, 3 SSLR 3381 (D. Minn. 1970). 
student deferment. The denial of his claim did not depend on any factfinding duty of the board, nor did the board have any discretionary authority. Since there were no issues for the appeal board to resolve, the court held it unnecessary to require the board to spend any fixed time considering the frivolous claim.

The decisions also suggest that adjustments in the quantum of time necessary to reverse the presumption of regularity will be made in an unusually simple or unusually complex case. United States $v$. Han$\operatorname{sen}^{111}$ deals with an unusually simple claim involving the interpretation of medical reports in the registrant's file. The claim was not a frivolous one since the registrant was entitled to his claim if the evidence supported it, and he had submitted some such evidence. The court held, however, that the reports were "self-evident" and that there was therefore no need for the average appeal to be of any particular length. The court contrasted the self-evident nature of the medical reports to the "insight and reflection" required of the appeal board during the consideration of a conscientious objector claim. ${ }^{112}$

Consideration by courts of the amount of time spent by appeal boards on cases should bring the Selective Service System closer to the ideal of a fair hearing for every registrant. For those registrants who take advantage of the right, effective March, 1972, to a personal appearance before an appeal board, the need to utilize circumstantial evidence to discern whether a fair hearing has taken place will be lessened. There will still, of course, remain the question whether the registrant received adequate consideration after he left the room. Under the 1971 Act, those registrants who are unable or do not choose to appear will still be faced with the problem of boards overloaded with work. ${ }^{113}$ Indeed, for these registrants the situation may deteriorate. If appeal boards are instructed to consider both appearing and nonappearing registrants at the same meeting, nonappearing registrants will probably be given short shrift in the time left over from the appearances. Although state and national directors have been directed by regulation to create new appeal board panels to accommodate the increased time required by the

111327 F. Supp. 1090, 4 SSLR 3443 (D. Minn. 1971).

112 Id. at 3444; accord, United States v. Page, - F. Supp. -, 5 SSLR 3308 (D. Minn. 1972).

113 Appeal board panels are established at the discretion of the Director of Selective Service. New Reg. \& 1604.22. Currently, there is an appeal board for each federal district court. Needless to say, it would involve considerable time and expense if each registrant were required to travel to the nearest courthouse city to obtain his personal appearance. Some registrants would be forced to (or would prefer to) forego their right to a personal appearance when faced with this obstacle. The Director has yet to take any action to indicate how he will deal with this problem. 
personal appearances, ${ }^{114}$ one may well wonder, in light of past tolerance for overload, if the problem will be satisfactorily solved. In addition to the possibility of being granted an even shorter appeal than formerly, the nonappearing registrant may also confront greater problems in making a showing of irregular procedure. The average time criterion outlined above would seem to offer little help to these registrants since the average time will have been extended by the personal appearances. Indeed, the only adequate protection may be a requirement that boards keep separate time records for nonfrivolous appeals. However, while such a record is not without costs, it is not unduly burdensome in light of the interests at stake.

2. The Appellate Resume. In an attempt to remedy the effects of the severe time pressure imposed by the procedural overload, most appeal boards have made it a standard procedure for a clerk to draw up a resume of each registrant's file before the appeal board meeting. ${ }^{115}$ This saves considerable time by enabling the board to decide the case without reference to the registrant's file. The clerk who compiles the resume does not necessarily possess any expertise in Selective Service law, and the product may therefore contain errors of law or omit significant

114 Old Reg. $\$ 1604.22$. New Reg. $\$ 1604.22$ places this power in the hands of the national Director.

115 Nowhere do the regulations provide for any resume to be compiled, but they are prepared in any event. This Review sent a questionnaire to all state directors and received a reply from the General Counsel of Selective Service. His answers verified that the use of resumes is standard practice. The letter confirmed the following: A resume is regularly prepared for the appeal board's use; it is a general summary of the material in the file and the basis for the requested deferment; it is prepared by an "experienced staff member" and is used in all cases; all members of the board see it, but the file itself may or may not ever be viewed; the resume is available up to one month prior to the meeting; it is never shown to the registrant and is destroyed after the meeting. Letter from Walter H. Morse, General Counsel, Selective Service System, to The University of Chicago Law Review, Nov. 30, 1971 [hereinafter cited as Morse Letter]. Mr. Morse was careful to note that his answers were obtained through a survey of state offices and do not reflect national Selective Service policy. Practices undoubtedly vary considerably, especially with regard to the skill of the preparer, the presence of the file, and the timing of the resume (some appeals are decided within two weeks total time).

In the Wallen case, the state headquarters sent an official to testify at the trial. He testified not that the full file was always read, but that the board members could have access to it if they desired and requested it of the secretary. In the Woloszczuk case, the board's secretary testified that the board saw the file only if the secretary had picked it out as a case deserving special attention. An extended discussion of the problems created by resumes is found in Gonzales v. United States, 364 U.S. 59 (1960). For mentions of the existence of, or discussions of the use of, the appellate resume, see HANDBOoK For ConsciENTIOUS OвJECTORS 24 (11th ed. A. Tatum 1970); Senate Hearings, supra note 4, at 246; Margolis, supra note 87, at 103; DrafT Counselor's Newst.ETTER (published by Central Committee for Conscientious Objectors), July, 1970; id., Aug., 1970; id., Issue 7, 1971, Midwest section 2; 3 SSLR NEwSLETTER 57 (1971); 4 id. 26 (1971). 
facts. ${ }^{116}$ The resume may condense a file of 150 pages to a four-sentence summary and may be drawn under intense time pressures. ${ }^{117}$ Sometimes resumes are not distributed to the appeal board members until the time of the actual meeting. ${ }^{118}$ Appeal boards not only favor the resume over the file itself, but also often refuse to read legal briefs submitted to them. ${ }^{119}$ After the appeal board meeting, the resume is routinely destroyed. ${ }^{120}$ At no time is it shown to the registrant. ${ }^{121}$

One such resume has appeared in a case, having apparently escaped destruction:

WOLOSZCZUK, Stephen L. B. \#38 (Worchester) \#19-38-49-135 1-A to 4-D(Reg:) Age 18. DOB 9/19/49. Reg. filed Form 150 and appeals for 4-D class. He is a Jehovah's Witness. He is presently a VACATION (not REGULAR) PIONEER until Apr.30, 1968. (Elig. for $1-O$ but not $4-D) .{ }^{122}$

The cases are split on the effect of such a resume. One line of cases responding to the mandates of the procedural overload sanctions the use of resumes if the use is fair. In one of these cases, United States $v$. Young, ${ }^{123}$ the court reasoned as follows:

If employed in a fair manner, this Court does not find efforts toward administrative efficiency repugnant to the demands of due process. It would clearly be impossible to require every board member to examine every document in every file. To do so would result in needless and vast expenditures of time and energy. ${ }^{124}$

The opinion unfortunately fails to address the critical question of what it means to employ a resume "in a fair manner." It is significant that while Young and similar cases ${ }^{125}$ refuse to condemn the use of the

116 See Sedler, supra note 11, at 1141.

117 Judge Henry Gwiazda, former Chairman of the National Appeal Board, testified to this fact in Senate Hearings, supra note 9, at 249, 252.

118 See United States ex rel. Scott v. La France, - F. Supp. -, 4 SSLR 3498 (N.D. Ohio 1971); United States v. Wallen, 315 F. Supp. 439, 3 SSLR 3125 (D. Minn. 1970); Sedler, supra note 11, at 1149; Morse Letter, supra note 115.

119 Cf. Senate Hearings, supra note 9, at 71.

120 Morse Letter, supra note 115.

121 Id. Even though Mr. Morse states that his answers do not indicate uniform policy, an instance cannot be found in which such a resume has knowingly been shown to the registrant.

122 United States v. Woloszczuk, 328 F. Supp. 696, 4 SSLR 3557, 8 (D. Mass. 1971).

123324 F. Supp. 69, 3 SSLR 3381 (D. Minn. 1970).

$124 \mathrm{Id}$. at 71,3 SSLR at 3382. The new regulations, however, do require such an inspection. See New Reg. \$§ 1622.1, 1626.4(g)-(h).

125 E.g., Welsh v. United States, 404 F.2d 1078, I SSLR 3233 (9th Cir. 1968), rev'd on other grounds, 398 U.S. 333 (1970); United States v. Tittlerud, - F. Supp. -, 2 SSLR 3283 (D. Minn. 1969). 
resume per se, neither do they allow the presence or use of a resume to substitute for an examination of the contents of the file.

The opposing line of cases focuses on the determinative influence of the clerk, concluding that the use of the resume is inherently unfair. The Wallen court held:

It was in reality but an appeal to the clerk of the appeals board only; for he or she is the one who makes the resume, who selects the matters to be emphasized and who omits what he or she may consider immaterial matters. ${ }^{126}$

In most areas of administrative law, reports and recommendations by subordinates are both allowed and encouraged. ${ }^{\mathbf{1 2 7}}$ There are, however, crucial differences between normal administrative processes and Selective Service cases that militate in favor of a different result in draft appeals. First, no briefs are submitted to the appeal board by the parties, nor is there an open adversary process accompanied by the full safeguards that normally attend administrative proceedings. If a resume is compiled, it may be the only thing on which the board relies. ${ }^{128}$ Second, since the appeal board members are volunteers, while the clerk is a full-time staff member, board members are apt to defer to the clerk's advice regardless of its validity. Third, since appeal boards proceed in secret and issue opinions rarely or cryptically, there is no way to ascertain the use actually made of the resume. Fourth, the appeal board is charged with the duty to conduct a de novo review of the case. If the resume is based solely on the proceedings below, and in fact contains less information than the local board relied on, such a de novo hearing cannot be afforded. ${ }^{129}$ As the court noted in United States ex rel. Scott $v$. La France: ${ }^{130}$

The [regulatory] language clearly and concisely places the responsibility of review and decision of appeals before the Board of Appeals upon a majority of a quorum of its members. This responsibility cannot be abdicated by the Board of Appeals by dele-

126315 F. Supp. 459, 3 SSLR 3125, 6 (D. Minn. 1970); accord, United States v. Leichtfuss, 331 F. Supp. 723, 4 SSLR 3525, 33 (N.D. Ill. 1971); cf. House Hearings, supra note 5, at 12877. Other subdelegations and abdications of board authority are probably also barred. United States v. Miller, No. 71-2040 (9th Cir., Feb. 11, 1972).

127 Reisner, supra note 12, suggests that even within the Selective Service System, a properly regulated resume procedure can produce superior results. He found that the Department of Justice hearing and resume procedure produced fewer legal errors on the part of the appeal board than it commits under the current procedure.

128 See text and note at note 115 supra.

129 New Reg. $\S \S 1626.4,1622$, 1624 command the appeal board to classify in the same manner as the local board and thus to look at all evidence in the file.

130 - F. Supp. 一, 4 SSLR 3493 (N.D. Ohio 1971). 
gating that responsibility and authority to its Executive Secretary. ... The review and decision of petitioner's appeal was in fact a review and decision of the Appeal Board's Executive Secretary, and perfunctorily rubber-stamped by individual members thereof. ${ }^{131}$

Finally, there is reason to believe that Selective Service resumes are drawn hastily and inexpertly in a way that cannot fail to prejudice the registrant when the resumes are utilized hurriedly. The burdens on appeal board time must necessarily compel reliance on the resume beyond any tolerable level. ${ }^{132}$

\section{B. The Right to Be Advised of the Evidence-Due Process and An- other Side of the Resume Practice}

If the resume contains an illegal standard for decision or factual errors or omissions, ${ }^{133}$ it is impossible for the reviewing court to rectify the error unless the resume is disclosed. There is strong precedent for the right to know the evidentiary basis on which decisions are made. Thus, even if courts are unwilling to void the resume practice in the face of current procedural overloads, alternative safeguards are available short of complete invalidation.

An excellent parallel exists between the appellate resume and the hearing procedure used prior to 1968 in conscientious objector cases. ${ }^{134}$ Under that procedure, the FBI gathered background material on the registrant. It then submitted this material to a Department of Justice hearing examiner, who interviewed the registrant and made a recommendation to the Department regarding the disposition of the case. The Department then recommended a disposition to the appeal board.135 For many years after this procedure was commenced, the registrant was

131 Id. at,- 4 SSLR at $3498-94$.

132 See notes 115-22 supra. The Woloszczuk resume, note 122 supra, illustrates this effect. The resume noted eligibility for 1-O but not for 4-D classification, and that was exactly the decision the appeal board made, even though the local board had also turned down the 1-O request and the registrant had made almost no effort to pursue that issue. This resume and abbreviated hearing process is self-reinforcing. The shorter the appeal time, the more reliance must be placed on the resume. The more the appeal board comes to rely on the resume, the more tempting it is to shorten the consideration given to each case.

133 The Woloszczuk resume contains such an error. The resume assumed that the name the Jehovah's Witnesses attached to the type of post that the registrant held controlled his eligibility. In fact, the relevant data are the number of hours per month he devoted to the ministry and whether the ministry was his primary vocation. See SSLR Pracrice MANUAI, If 1068 (1968).

134 See 1 K.C. Davis, supra note 11, I 7.14 (1958, 1970 Supp.); Reisner, supra note 12.

135 In most cases, the appeal board followed the Department's recommendation. See Reisner, supra note 12, at 528; Sedler, supra note 11. 
not allowed to see any of the materials concerning his case. ${ }^{136}$ A series of court decisions then established that the registrant was entitled to see two products of the process: a fair resume of the material contained in the FBI report and the Department of Justice's recommendation to the appeal board. In Simmons v. United States, ${ }^{137}$ the Supreme Court found that if a fair resume of the FBI report were not furnished, the registrant would be unable to meet the evidence against him. Subsequently, the court held in Gonzales $v$. United States ${ }^{138}$ that the registrant must be furnished a copy of the Department's recommendation. The Court stated that the registrant would be denied a meaningful appeal unless he was cognizant of all the information coming before the appeal board and was enabled to counter and rebut adverse material.

In similar holdings designed to provide registrants with knowledge of the facts crucial in the actual decision-making process, courts have held that relevant information must be placed in the registrant's file $\mathrm{e}^{139}$ and that the registrant must be advised of all such potentially harmful or prejudicial information. ${ }^{140}$ Yet such holdings have been circumvented by the physical separation of file and resume. The resume is not placed in the file, but is destroyed. The clear thrust of these due process requirements should not, however, be avoided by such formalisms. When the resume acts as a substitute for all the evidence and provides the foundation for appeal board decisions, due process must provide for full disclosure to the registrant.

\section{The Rights to an Opinion and a Transcript-Appeal Board Silence}

Since the scope of review of an appeal board decision with respect to the facts of the case is extremely narrow, and the appeal board decision is unlikely to be upset on this basis, it is quite important to know exactly what procedures the appeal board has followed in each individual case. In a normal administrative or judicial proceeding, the due process rights to an opinion and a transcript would supply the information. Un-

136 United States v. Nugent, 346 U.S. 1 (1953), marks the first substantial crack in this policy. Cf. Gonzales v. United States, 364 U.S. 59 (1960); United States v. Purvis, 403 F.2d 555, I SSLR 3228 (2d Cir. 1968); De Remer v. United States, 340 F.2d 712 (8th Cir. 1965); Blalock v. United States, 247 F.2d 615 (4th Cir. 1957).

137348 U.S. 397 (1955). The court then noted: "A fair resume is one which will permit the registrant to defend against the adverse evidence-to explain it, to rebut it, or otherwise detract from its damaging force." Id. at $\mathbf{4 0 5 .}$

$138 \mathrm{Id}$. at 407.

130 Reg. § 1621.12; see cases cited in Shattuck, Record Keeping Obligations of Local Boards, I SSLR 4015 (1968). The registrant is allowed access to his file. Reg. $\S 1606.32(a)(1)$.

140 E.g., United States v. Cabbage, 430 F.2d 1037, 3 SSLR 3179 (6th Cir. 1970); United States v. Owen, 415 F.2d 383, 2 SSLR 3233 (8th Cir. 1969); Smith v. United States, 157 F.2d 176 (4th Cir.), cert. denied, 329 U.S. 776 (1946). 
fortunately, Selective Service appeal boards only occasionally issue an opinion and never supply a transcript.

1. Written Opinions. In the Selective Service context, an opinion is normally referred to as a statement of reasons, or simply as reasons. The reasons given by a board, if they are advanced at all, are abbreviated and usually vague, ${ }^{141}$ although reasons that are purely conclusory are not accepted by the courts. ${ }^{142}$ The 1971 Act and the regulations issued pursuant to it require appeal boards to give brief reasons for all decisions; ${ }^{143}$ accordingly, the discussion that follows applies only to those registrants whose cases will have been decided prior to March, 1972.

Appeal boards are now required by case law in most circuits to give reasons for their decisions where the registrant has made a prima facie claim of conscientious objector status and no obvious basis in fact for denying the claim appears in the file. ${ }^{144}$ The due process requirement for reasons springs from the review standards established in Sicurella $v$. United States. ${ }^{145}$ There, the Supreme Court held that reliance by the board on an illegal basis for the classification would require acquittal, even though valid reasons also appeared. The presence of an illegal ground for the decision made it impossible for the Court to determine what weight had been placed on the legal ground. It is quite possible, the Court said, that had the board known that one of its grounds was incorrect, it would not have invoked the other ground at all.

141 See, for example, reasons recited by the court in United States ex rel. Stein v. Gillen, 332 F. Supp. 953 (N.D. Ill. 1971).

142 United States v. Atherton, 430 F.2d 741, 3 SSLR 3265 (9th Gir. 1970); Batterton v. United States, 260 F.2d 233 (8th Cir. 1958); Morin v. Grade, 301 F. Supp. 614, 3 SSLR 3067 (E.D. Wisc. 1970); United States v. St. Clair, 293 F. Supp. 337, I SSLR 3224 (E.D.N.X. 1968); Hansen, supra note 58, at 478. But see United States v. Stickler, 452 F.2d 907, 5 SSLR 3046 (9th Cir. 1971).

143 New Reg. $\S \S 1623.4(c), 1624.6,1625.4,1626.3(\mathrm{a}), 1626.4(\mathrm{i}), 1627.4(\mathrm{~h})$ all require reasons in a variety of situations.

144 Eight circuits have such a requirement in one form or another. United States v. O'Bryan, 450 F.2d 365, 4 SSLR 3678 (6th Cir. 1971); United States v. Edwards, 450 F.2d 49, 4 SSLR 3583 (1st Cir. 1971); United States v. Stetter, 445 F.2d 472, 4 SSLR 3199 (5th Cir. 1971); United States v. Speicher, 439 F.2d 104 (3d Cir. 1971); United States v. Lenhard, 437 F.2d 936 (2d Cir. 1970); Caverly v. United States, 429 F.2d 92 (9th Cir. 1970); United States v. Broyles, 423 F.2d 1299 (4th Cir. 1970); United States v. Haughton, 413 F.2d 736 (9th Cir. 1968). The Tenth and District of Columbia Circuits have no cases on the issue. Some of these cases allow district courts to dig quite deeply into the file in order to find defects in the claim obviating the requirement that the board state reasons. $C f$. United States v. Atherton, 430 F.2d 741, 3 SSLR 3265 (9th Cir. 1970). The Solicitor General recently confessed error in a case where an admittedly prima facie claim was denied without reasons. Joseph v. United States, 92 S. Ct. 1274 (1972).

145348 U.S. 385 (1955). See generally Comment, Administrative Findings in Selective Service Litigation, 57 VA. L. REv. 477 (1971). 
In 1971, Glay $v$. United States ${ }^{146}$ expanded the Sicurella doctrine to include all cases in which the appeal board even arguably relied on an invalid ground for decision, implicitly holding that the only way to insure that such reliance did not occur was to require reasons for the board's decisions.

Several courts have combined Sicurella and Glay to expand the reach of the requirement that reasons be stated. ${ }^{\mathbf{1 4 7}}$ There seems to be no reason to confine the requirement to cases of conscientious objection or prima facie claims. ${ }^{148}$ In addition to enabling the courts to provide meaningful review, the requirement of reasons is equally important if the registrant himself is to make a meaningful appeal statement to the National Appeal Board. Many courts have focused on the registrants' right to know the facts and theories on which the board relied and to which the statement of appeal must be addressed. ${ }^{149}$

2. Transcripts. Draft counselors currently advise each registrant to make as full a record of the personal appearance as he can and mail it to his draft board..$^{150}$ This dialogue from immediate recollection is usually the best record obtainable of what actually transpired at the appearance. Courts do not currently consider access to a transcript of the registrant's rights. It has been held that the registrant has no right to

146403 U.S. 698, 4 SSLR 3258 (1971).

147 E.g., United States v. Beckham, 330 F. Supp. 1099, 4 SSLR 3690, 3691 (W.D. Mich. 1971). The Sixth Circuit has also combined Sicurella and Clay to extend the requirement of reasons: "A reviewing court faced with a silent file may only speculate as to what factors motivated a given determination." United States v. O'Bryan, 450 F.2d 365, 4 SSLR $3678^{\circ}$ (6th Cir. 1971). But the Ninth Circuit declines to require reasons to deny a 2-A claim, even if prima facie. United States v. Marcovich, 454 F.2d 138, 5 SSLR 3078 (9th Cir. 1972).

148 A few very recent cases have required the appeal board to state reasons even where no prima facie claim has been made out. For example:

[W] here a claim is made out, as here, for conscientious objector status, and the sole record on review is a notion that the claim was considered and rejected, and there is no explanation for the rejection, a very real problem arises as to whether the registrant has been afforded due opportunity for administrative or judicial review of the local board's action.

United States v. Neamond, 452 F.2d 25, 4 SSLR 3750 (3d Cir. 1971); cf. United States v. Gyekis, 446 F.2d 1364, 4 SSLR 3398 (3d Cir. 1971); United States v. Crownfield, 439 F.2d 839, 3 SSLR 3833 (3d Cir. 1971); United States v. Lemmens, 430 F.2d 619, 3 SSLR 3185 (7th Cir. 1970); United States v. Auger, 337 F. Supp. 342, 5 SSLR 3193 (N.D. Cal. 1972); United States v. Reese, 331 F. Supp. 1088, 4 SSLR 3658 (N.D. Ga. 1971); United States v. Nathan, - F. Supp. -, 3 SSLR 3190 (N.D. Cal. 1970); Reisner, supra note 12.

149 E.g., United States v. Edwards, 450 F.2d 49, 4 SSLR 3583 (1st Cir. 1971); United States v. Crownfield, 439 F.2d 839, 3 SSLR 3833 (3d Cir. 1971); United States v. Abbot, 425 F.2d 910, 2 SSLR 3651 (7th Cir. 1970); cf. Vitarelli v. United States, 359 U.S. 535 (1959); Gonzales v. United States, 348 U.S. 407 (1955).

150 See HandBook for Conscientious ObJectors 22 (11th ed. A. Tatum 1970). 
bring a stenographer to the personal appearance. ${ }^{151}$ In addition, a recent national Selective Service directive specifically prohibited boards from allowing the registrant to bring a tape recorder. ${ }^{152}$

A transcript could be of great value in at least three types of situations. First, where the board has failed to offer reasons for its decision, or where the reasons are vague and conclusory, the transcript would allow a court to infer bases for decision from the lines of questioning pursued. In particular, if the questioning revealed that an illegal basis for decision was being utilized, the registrant could be afforded another hearing. ${ }^{153}$ Second, where there is some question as to the evidence the registrant produced verbally to support his classification or, conversely whether the registrant provided some basis in fact to deny his claim, the transcript would provide a conclusive answer. Numerous cases turn on just such an evidentiary problem. ${ }^{154}$ Finally, a transcript would enable the registrant to show conclusively any prejudice that the board might evince, either toward the registrant personally or toward some entire class of claims (such as conscientious objection). ${ }^{155}$

Transcripts are clearly an accepted element of the administrative process and are generally included within the elements of due process. ${ }^{158}$ Under the conditions of Selective Service appeals, they appear to be indispensable in enabling the court to exercise a meaningful review. Moreover, there is no indication that the provision of a transcript would in any way impede the functioning of the Selective Service System since it need be nothing more than a recording of the personal appearance. Current Department of Defense regulations allow an in-service conscientious objector claimant to make, at his own expense, a transcript of any of the proceedings involved in his processing. ${ }^{157}$ There appears to be no reason why the transcript should not also be allowed

151 Uffelman v. United States, 230 F.2d 297, 303-4 (9th Cir. 1956). Under the new regulations permitting the registrant to bring witnesses with him to his personal appearance, it might be possible, at the considerable risk of incurring hostile reactions from the local board members, for the registrant to be accompanied by a stenographer. This stratagem cannot work before the appeal board, however, since witnesses are not admitted. Cf. SSLR Practice Manual of 1080.

152 Letter to All State Directors 00-43, SSLR 2200:89 (Oct. 26, 1971).

153 See Sicurella v. United States, 348 U.S. 385 (1955).

154 E.g., United States v. Iverson, 455 F.2d 79, 5 SSLR 3120 (8th Cir. 1972).

155 Such prejudice would be a clear basis for invalidating an induction order. See, e.g., Wills v. United States, 384 F.2d 943 (9th Cir. 1967); SSLR Practice MANUAL II 1072, 1075. 158 Goldberg v. Kelly, 397 U.S. 254 (1970); In re Gault, 387 U.S. 1 (1967); cf. Administrative Procedure Act § 5(d), 5 U.S.C. § 556(d) (1970).

157 Department of Defense Directive 1300.6, SSLR 2325 (Aug. 20, 1971). 
or required before an appeal board in light of its potential usefulness to both the registrant and the Government.

\section{A Due Process Model for Appeal Board Procedure}

Based on the preceding discussion, it seems reasonable to estimate that of the serious appeals taken by registrants, at least ninety percent are not conducted in accord with the demands of due process. ${ }^{158}$ The personal appearances and statements of reasons required by the 1971 Act and regulations will reduce this percentage for persons processed after March, 1972, but it will still be a substantial figure. A realistic program to remedy the problem is not, however, difficult to devise. The following model procedure could provide maximum safeguards for the registrant without interfering with any need for expeditious processing, if such a need is thought to be important.

In accordance with current regulations, ${ }^{159}$ more appeal board panels would be created to alleviate the administrative overload. These would be scattered throughout the state, so that the registrant could exercise his right to a personal appearance without the need for extensive travel. The additional panels would also enable speedier consideration of cases and thus create some additional time for the procedures outlined below. When an appeal was taken, an experienced staff member would draw up a resume of the file, extract any documents crucial to the case, and send the resume to appeal board members and the registrant. The registrant would then have ten days in which to draw attention to any inadequacy in the resume and to submit any response he might wish to make to its contentions and recommendations. He could point out any part of his file that he thought was crucial, but which was overlooked or omitted. The appeal board would then decide the case on the basis of the resume and the registrant's answer, consulting any parts of the file to which the registrant had drawn attention. If the registrant chose to exercise his right to appear, he could be accompanied by witnesses and counsel. Imposition of a reasonable time limit on the proceeding would prevent significant delay. The same papers would be used whether or not the registrant appeared. The appeal board meeting would be recorded to provide a transcript, and the board would automatically furnish a short statement of the reasons for the decision and the facts that were relied upon. Special time would be set aside at the meeting for consideration of "difficult" cases. The members of the

158 On the length of time and appellate resume issues alone, almost all Selective Service classifications would falter.

159 New Reg. \& 1604.22. 
appeal board would be required to have read all crucial documents before coming to the meeting.

In order to save further time for the procedure outlined above, the appeal board or its staff member would be allowed to designate any appeal as "frivolous" and thereby omit all the above steps. The resume would be drawn by the staff member and submitted directly to the board. To safeguard fully the rights of the registrant, however, should his case later come before a court, that court would hold a de novo classification proceeding. ${ }^{160}$ Such a procedure would act as protection in the event that a fully substantiated claim were dismissed as frivolous.

The procedure outlined above is not radical, but is necessary. It would provide basic procedural rights in the Selective Service System, and thereby assure the protection of the interests of the registrant, where little such protection now exists.

Frank H. Easterbrook

160 This should be no burden on the Government since by hypothesis it would occur only when the claim were untenable. Indeed, most registrants would accept induction rather than risk an almost certain criminal conviction. The object of the de novo hearing would be simply to ensure that at some point in the proceedings, the registrant received a full and fair hearing of his claim, however frivolous it might seem to the appeal board. 